\title{
COSOLVENTS IMPACT ON SOME PROPERTIES OF THE SOLUTIONS AND THE FILMS OF SUCCINAMIDE CHITOSAN
}

\author{
Marina Bazunova1, ${ }^{凶}$, Valentina Chernova1, Roman Lazdin', Angela Shurshina1, \\ Anna Bazunova ${ }^{1}$, Mariya Elinson, Elena Kulish ${ }^{1}$
}

https://doi.org/10.23939/chcht14.04.481

\begin{abstract}
The article deals with the method of the medical purpose materials creation with the controlled physico-chemical and mechanical deformation properties on the basis of water-soluble derivative of amino polysaccharide chitosan - succinamide chitosan. The essence of the method is the macromolecules aggregation processes regulation in the initial solutions by the injection of organic cosolvents - acetone and ethanol. It has been stated that in a mixed solvent succinamide chitosan molecules are not in the form of the isolated macromolecular balls but as the macromolecules interacting (aggregated) systems. It has been proved that the presence of cosolvents decreases the polymer macromolecule links capability to interact with an enzyme and increases physico-mechanical characteristics of the film materials.
\end{abstract}

Keywords: sodium salt of succinamide chitosan, cosolvent, relative viscosity, enzyme degradation, degree of aggregation, sorption curve.

\section{Introduction}

A number of requirements is imposed on the modern polymer materials of a biomedical purpose. Firstly, such properties as biocompatibility with the body tissues, the bacteriostasic, the ability to biodegradation are desirable and in some cases obligatory [1]. Secondly, biomaterials for the medical treatment, for example, for surface wounds and burns, should have good water vapor permeability, a high sorption capacity to the wound effluent, a transparence (i.e. a possibility of monitoring the process of the skin regeneration) and an ability to protect a wound from a pathogenic microflora.

The amino polysaccharide chitosan (ChT) and its derivates, for example, succinamide chitosan (SChT) [2-5] may become a fine basis for creating this sort of materials.

\footnotetext{
${ }^{1}$ Bashkir State University

32, Zaki Validi St., 450076 Ufa, Republic of Bashkortostan

mbazunova@mail.ru

(C) Bazunova M., Chernova V., Lazdin R., Shurshina A., Bazunova A., Elinson M., Kulish E., 2020
}

It is known that $\mathrm{ChT}$ and its derivatives are the associating polyelectrolytes, for its macromolecules consist of soluble charged parts of the chain and the insoluble groups distributed along the chain - the stickers which are capable to aggregate with each other and to form the thermo reversible bonds $[6,12]$. Knowing the regularities of the polymer molecular organization in the dilute solutions of the individual macrochains and the factors specifying it, we may directly obtain nanodimensional particles or capsules that can be used, for example, as the carriers of the medical preparations while the polymer behavior features in a stronger solutions is necessary for the stipulation of physicochemical regularities of the films formation and the materials from the solutions.

One of the ways of medical purpose materials creation with the controlled sorption, physico-chemical and deformation-strength properties on ChT and its derivatives basis is the regulating by the macromolecules aggregation processes in the initial solutions [6-11] that is shown as the polymer viscous characteristics change in the solution. Studying ChT and its derivatives behavior in various concentration areas (the diluted, the semi-diluted and the concentrated solutions) allows to obtain the data about the intermolecular aggregation level and, therefore, to find approaches to the directed formation of physicomechanical properties complex of the material created from the solution.

To control the macromolecules association (aggregation) processes in the polymer solution and, respectively, the modification of the materials properties obtained from the solution, various modifying additives may be injected into the solution, for example cosolvents $[6,13,14]$. Another possible reason for the solvent injection into the polymer solution is the decrease of the drying time of the material obtained from the aqueous solutions.

If the injected cosolvent has a higher evaporation rate, than in the aqueous medium it is combined with the aqueous solutions and is capable to form an azeotropic mixture with water. It is reasonable to inject this component into the forming solution. However, whatever 
the purpose of the cosolvent injection into the polymer solution is, its injection can principally affect the polymer viscosity.

Thus, this work is devoted to the study of the viscous characteristics of the SChT aqueous solutions in the presence of the organic cosolvents intjected for the processes regulation of the intermolecular aggregation. Ethanol and acetone were used as cosolvents.

\section{Experimental}

In the work SChT with $\mathrm{MM}=207 \mathrm{kDa}$ and the intrinsic viscosity $[\eta]_{0}=3.60 \mathrm{dl} / \mathrm{g}$, with the replacement degree by amino groups of $75 \%$ produced by CJSC Bioprogress (Schelkovo, Russia) was used. The deacetylation degree of the initial chitosan sample from which SChT had been obtained was $82 \%$. SChT.

The distilled water was used as the main solvent of

The SChT solutions in the mixed solvent were prepared, carrying out the dissolution of a certain polymer amount to water, previously diluted with ethanol (acetone) in a ratio of 90:10; 80:20 and 70:30 v/v \%.

The relative and "current" intrinsic polymers viscosity $[\eta]_{0}$ was determined by means of Ubbelohde viscometer at $T=298 \pm 1 \mathrm{~K}$ by Baranov's method [12]. To determine the aggregation degree $\delta$ they proceeded from a reasoning that if the contribution to viscosity is made not by separate particles, but by their aggregates, the volume of which depends not only on the number of particles $n$ contained in it, but also on their packing density, then as a result of an incompact packing of particles in the aggregate their contribution to the viscosity began to depend on the concentration non-linearly that demonstrates $\delta$ deviation from 1 :

$$
\Delta \eta \sim \eta_{0} c^{\delta}, \delta>1
$$

where $\Delta \eta=\left(\eta_{s o l}-\eta_{0}\right)$ is the difference between the relative viscosity $\eta_{\text {sol }}$ of the solution and $\eta_{0}$ of the solvent.

Respectively $\Delta \eta / \eta_{0}$ is the value of the specific viscosity. Thus, the processing of the experimental dependences of the specific viscosity of the polymers solutions on the concentration in the double logarithmic coordinates allows determining a degree indicator of $\delta$ as a slope tangent of this dependence.

The SChT films from the individual and the mixed solvents were prepared by the method of polymer solutions watering with the concentration of $1 \mathrm{~g} / \mathrm{dl}$ on the previously degreased surface of the Petri dish. The thickness of the films samples was kept constant and equal to $0.1 \mathrm{~mm}$.

The process of the enzymatic degradation of the polymer film samples was carried out at the temperature of $310 \pm 1 \mathrm{~K}$, keeping the films during some time $t$ on the substrate containing the enzyme solution in an amount of $1 \mathrm{mg}$. Hyaluronidase was used as the enzyme preparation. Further on, the process of the enzymatic destruction was stopped by boiling the sample during $30 \mathrm{~min}$ in a water bath, after that the film was dissolved in the distilled water with the subsequent determination. After that the values of the intrinsic viscosity of $\eta_{t}$ solutions of the film samples subjected to the destruction were determined. It judged about the process depth by $\Delta \eta / \eta_{0}$ value expressed in percents, where $\Delta \eta=[\eta]_{0}-[\eta]_{t}$, and $[\eta]_{0}$ is the intrinsic viscosity of the polymer sample not subjected to the destruction.

The degree of swelling of the film samples was evaluated by the desiccator method at $100 \%$ humidity in the thermostatically controlled conditions $T=298 \pm 1 \mathrm{~K}$. The relative amount of water $m_{t}$ absorbed by the polymer films at the time $t$ was determined with the accuracy by the weight up to $10^{-4} \mathrm{~g}$, keeping the film samples in the desiccator in the water vapors for a predetermined time, and calculated them by the formula:

$$
m_{t}=\frac{\Delta m_{t}}{m_{0}} \cdot 100 \%
$$

where $m_{0}$ is the mass of the initial film, g; $\Delta m_{t}$ is the difference between the film mass at an instant time $t$ and the initial film mass.

For the stipulation of the sorption mode the results are processed by the equation:

$$
\frac{m_{t}}{m_{\infty}}=k t^{n}
$$

where $m_{\infty}$, in case of limitedly swelling polymers, corresponds to the value $m_{t}$ at $t \rightarrow \infty$; in case of unlimitedly swelling polymers the value of $m_{t}$ was taken as the maximum value $m_{t}$ achieved in the sorption process, after reaching it, the film mass began to decrease as a result of the dissolution; $k$ is the constant associated with the parameters of polymer-diffusing interaction; $n$ is the index characterizing the sorption mode. The value $n$ is defined from the logarithmic anamorphosis dependence.

Physico-mechanical properties of the films were studied on the universal tension testing machine AGS-10 kNG "Trapezium-X" of the Shimadzu brand equipped with the Plastic Tensile Test program (the length of the sample base is $20 \mathrm{~mm}$, the width is $20 \mathrm{~mm}$, the thickness is $0.1 \mathrm{~mm}$, the stretching rate is $1 \mathrm{~mm} / \mathrm{min}$.). The ultimate tensile stress $(\sigma)$ was defined taking into account the sectional area of the sample taken for the tests and was expressed in MPa. The specific elongation at the rupture $(\varepsilon)$ was calculated taking into account the tentative length of the film sample taken for the test and was expressed in percents. The values of the specific elongation at the rupture and an ultimate tensile stress were calculated as an arithmetic average of five parallel measurements. 


\section{Results and Discussion}

Since SChT, like ChT, is an associative polyelectrolyte, the visually observed complete solubility of the polymer does not, in principle, exclude the presence of the macrochains dynamic aggregates even in heavily dilute polymer solutions. As a result, the solution can be a system of the interacting chains even in the field of dilute solutions, i.e. when the polymer concentration in the solution $c$ is less than $c^{*}$ (where $c^{*}$ is the so-called concentration of the crossover specifying the overlap concentration of the macromolecular balls and defined as the reciprocal value of the intrinsic viscosity $\left.c^{*}=1 /[\eta]\right)$.

The determination of the slope in the double logarithmic coordinates of the dependence of the SChT solutions specific viscosity in water and mixed aqueousorganic solvent allows us to make an unambiguous conclusion whether these solutions are aggregated. As it is seen in Fig. 1 (curve 1), in the dilute solutions of SChT in water the formation of the macromolecules true solutions that do not interact with each other takes place (the value of the parameter $\delta=1$ ). However, the injection of the organic cosolvents results in the change of the conformational-supramolecular state of the polymer in the solution which is demonstrated by the intrinsic viscosity decrease (Fig. 2) and the increase of macromolecules aggregation degree in the solution (Fig. 1, curves 2-4). The slope of the specific viscosity dependence from the polymer concentration in the solution is more than 1 for the SChT solutions in the presence of cosolvents. Thus, the SChT solutions in the presence of cosolvents are the aggregated solutions of the interacting macromolecules. It can be noted that the higher the cosolvent content in the system and the higher the polymer concentration in the

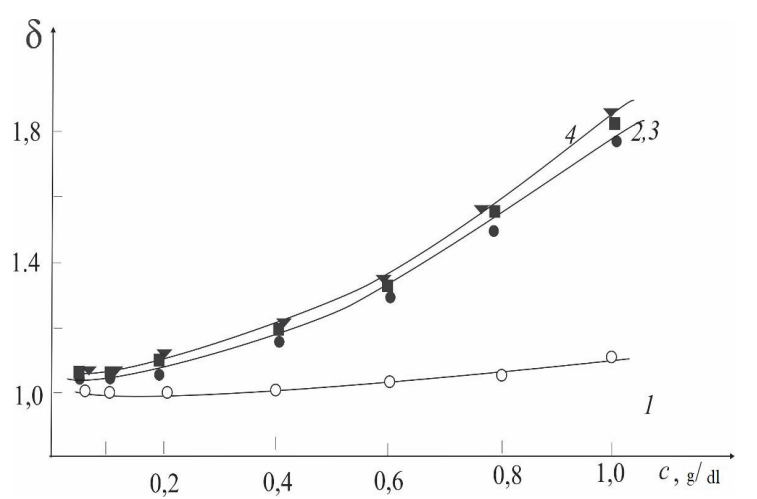

Fig. 1. The dependence of the macromolecules aggregation degree on the SChT concentration in the aqueous solution (1); in the mixed water-ethanol $(2,3)$ and water-acetone (4) solvents with the components ratio $(\mathrm{v} / \mathrm{v}, \%)$ of 90:10 (2) and 80:20 $(3,4)$ solution, the greater the degree of the aggregation and the lower the "current" intrinsic viscosity value.

The decrease in the intrinsic viscosity (Fig. 2) is easily explained by the compression of the macromolecular balls caused by the deterioration in the thermodynamic quality of the solvent (SChT is dissolved only in the mixed solvents, but not in the individual ethanol and acetone). But the deterioration of the solvent quality results not only in the change of the macromolecules conformation but also in the change of the supramolecular polymer state in the solution (the degree of the macromolecules aggregation). The first one results in the viscosity decrease, and the second one - in its increase. As a result, the regularities observed for the diluted and strong solutions are directly opposite. The polymers viscosity in the mixed solvents is less in the dilute solutions and in more concentrated solutions it is higher, than the viscosity in the individual solvents. It is vividly seen in Fig. 3, which shows the dependence in the relative viscosity change of the SChT solutions in the absence and in the presence of ethanol.

The viscosity increase caused by the strengthening of the aggregation processes in the SChT solutions in the mixed solvents can have a number of important consequences. Firstly, the increase of the aggregation degree may cause the increase in the polymers resistance to the enzymatic degradation process. The importance of the above is stipulated by the fact that in spite of this the ability to biodegradation is one of the polysaccharides huge advantages. A fast decomposition of the materials based on polysaccharides under the influence of the enzymes can also become the factor limiting their application and reducing the time of their service in case of the medical application.

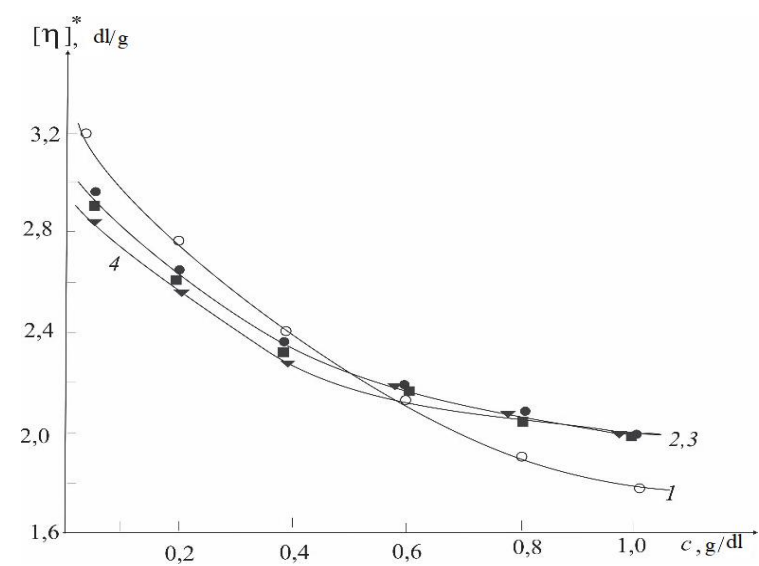

Fig. 2. The dependence of the "current" intrinsic viscosity value on the SChT concentration in the aqueous solution (1); in the mixed water-ethanol $(2,3)$ and water-acetone (4) solvents with the components ratio (v/v, \%) of 90:10 (2) and $80: 20(3,4)$ 


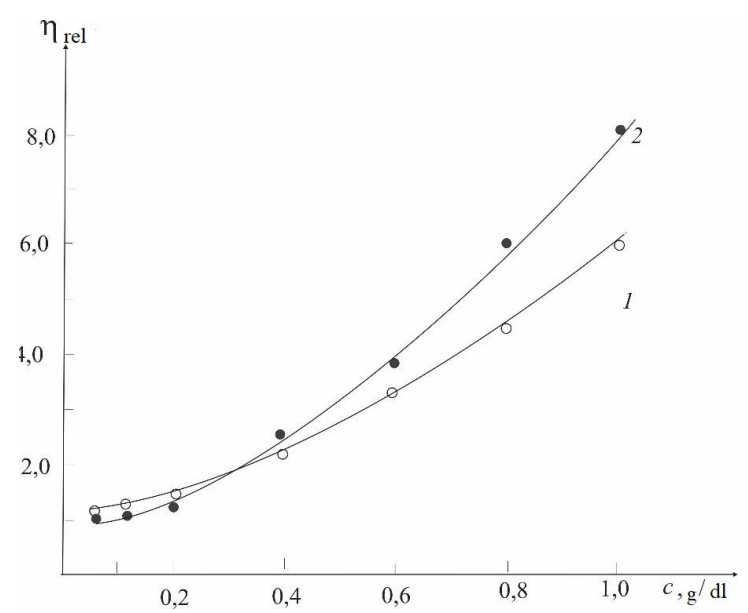

Fig. 3. The dependence of relative viscosity on the SChT solution concentration in water (1) and in the mixed wateralcohol solvent (2) with the components ratio 80:20 v/v \%

As it is seen in Fig. 4, the allowance of the SChT solutions with the enzyme preparation is followed by the viscosity decrease and the molecular mass decrease as well. At the same time, the same tendency remains for the SChT solutions: polymer degrades rather more slowly and to a lesser degree in the mixed solvents, than in water. The decrease of the enzymatic decomposition process rate of SChT in the mixed solvents can be explained by the strengthening of the aggregation processes causing the decrease of availability of macromolecules links for the interaction with the enzyme preparation.

Secondly, the differences in the viscosity characteristics of the SChT solutions in the individual and the mixed solvents also remain in the transfer to the condensed systems (films). For example, the changes happening in the polymer

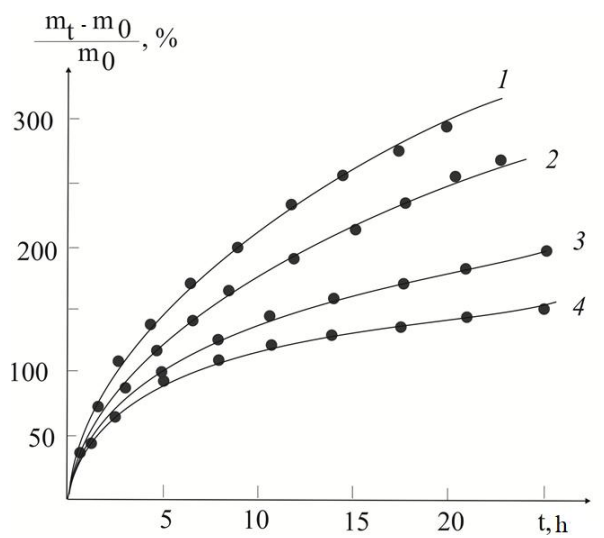

Fig. 5. Sorption curves of water vapors for SChT films obtained from the solution in the individual (1) and the mixed water-acetone (2-4) solvent with the components ratio (v/v \%) of: $90: 10(2) ; 80: 20(3)$ and 70:30 (4)

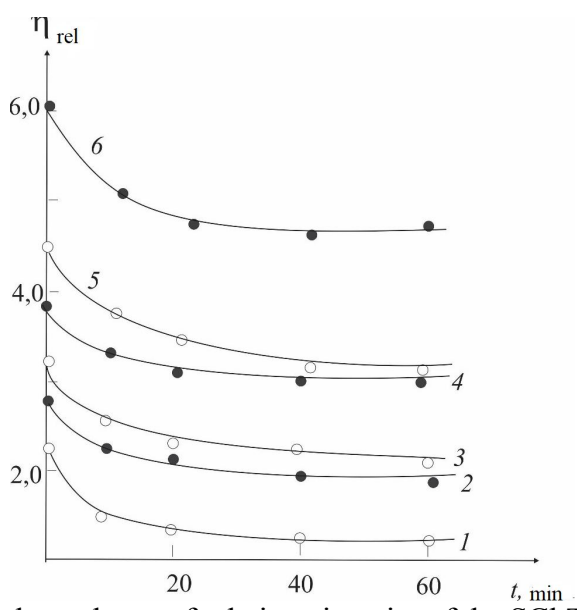

Fig. 4. The dependence of relative viscosity of the SChT solution in water $(1,3,5)$ and the mixed water-alcohol solvent $(2,4,6)$ with the concentration of $0.4(1,2) ; 0.6(3,4)$ and $0.8(5,6) \mathrm{g} / \mathrm{dl}$ on time.

The solvent components ratio is $80: 20 \mathrm{v} / \mathrm{v} \%$

structure affect the sorption process of water vapors. In Fig. 5 , where the SChT sorption curves are given as an example, obtained in the presence of acetone (modifying additive), one can clearly see that the films obtained from the mixed solvent and characterized by a higher aggregation degree, the lower rate and sorption degree of the water vapors.

Thirdly, one may note that for the films obtained from the mixed solvent, other physico-mechanical characteristics are common. As it is seen in Fig. 6, where the deformation-strength dependence of the SChT films is given, the presence of a small amount of co- solvent (up to $10 \mathrm{vol} \%$ ) causes the increase of the ultimate tensile stress values. A similar effect on the physico-mechanical properties of SChT is exerted by injecting ethanol into SChT-water system (Fig. 7).

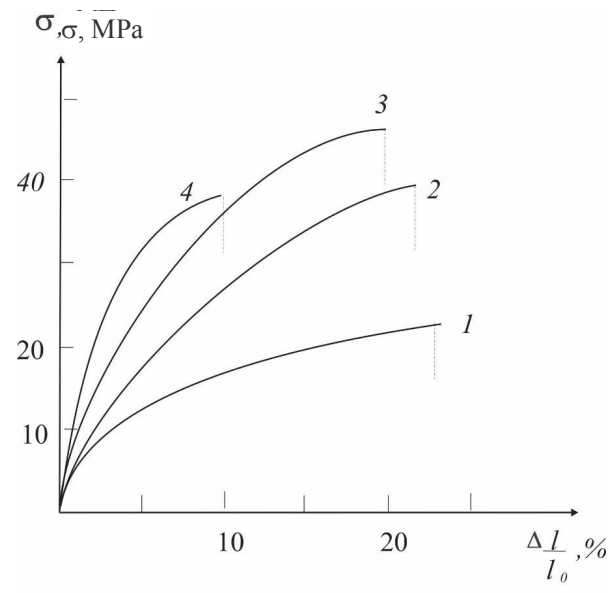

Fig. 6. Stress-strain curves for SChT films obtained from the solution in the individual (1) and the mixed wateracetone (2-4) solvent with the components ratio (v/v \%) of: 90:10 (2); 80:20 (3) and 70:30 (4) 
Fig. 7. The dependence of the ultimate tensile stress $(1,2)$

and stretch at break $(3,4)$ of the SChT films on the content of cosolvent ethanol $(1,3)$ and acetone $(2,4)$

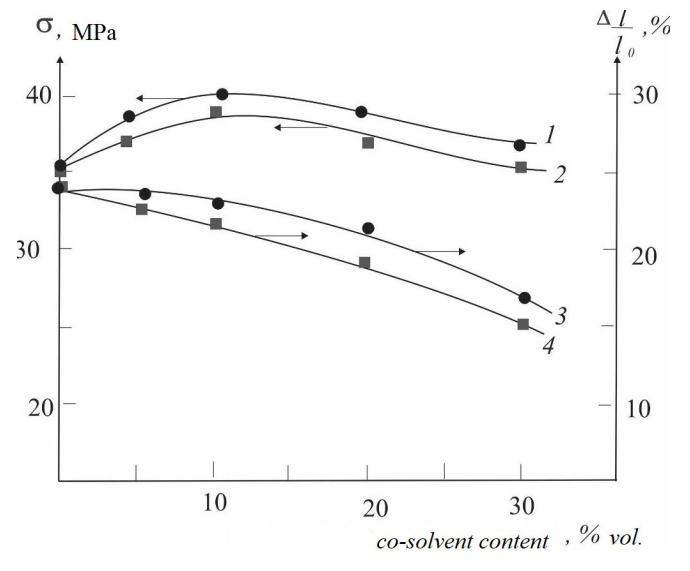

scientific activity within the framework of the basic part of the state task.

\section{References}

[1] Shishatsky O., Shishatskaya E., Volova T. Razrushaemyie Polimery: Potrebnosti, Proizvodstvo, Primenenie. Sib. federalnyii un-t, Un-t biofiz SO RAN, Krasnoyarsk 2010.

[2] Ilina A., Varlamov V., Ermakov Yu. et al.: Doklady Akad. Nauk, 2008, 421, 199.

[3] Slivkin A., Lapenko V., Arzamastsev A. et al.: Vestnik

Voronezh. Gos. Univ., 2005, $2,73$.

[4] Bazunova M., Sharafutdinova L., Bazunova A. et al.: Chem.

Chem. Technol., 2018, 12, 43.

https://doi.org/10.23939/chcht12.01.043

[5] Feofilova E.: Prikl. Biokhim. Microbiol., 1984, 20, 147.

[6] Bazunova M., Shurshina A.. Chernova V. et al.: Russ. J. Phys. Chem. B, 2016, 10, 1014.

https://doi.org/10.1134/S1990793116060178

[7] Popadyuk N., Zholobko O., Donchak V., et al.: Chem. Chem. Technol., 2014, 8, 171. https://doi.org/10.23939/chcht08.02.171

[8] Solomko N., Budishevskaya O., Voronov S. et al.: Macromol. Biosci., 2014, 14, 1076.

https://doi.org/10.1002/mabi.201300512

[9] Ageev E., Vikhoreva G., Matushkina N. et al.: Vysokomol.

Soed., 2000, 42, 333.

[10] Safronov V., Zubarev A.: Polymer, 2002, 43, 743.

https://doi.org/10.1016/S0032-3861(01)00513-4

[11] Uspensky S., Vikhoreva G., Sonina A. et al.: Khim. Volokna, 2010, 2, 11.

[12] Philippova O., Korchagina E., Volkov E. et al.: Carbohydrate Polym., 2012, 87, 687.

https://doi.org/10.1016/j.carbpol.2011.08.043

[13] Shilova C., Zinurova O., Husainova R. et al.: Vestnik Kazan. Univ., 2013, 16, 83.

[14] Sonina A., Vikhoreva G., Morgunov G., Galbreich L.: Khim. Volokna, 2012, 2, 7.

[15] Baranov V., Brestkin Yu., Agranova S. et al.: Vysokomol.

Soed. B, 1986, 28, 841 . 


\section{ВПЛИВ КО-РОЗЧИННИКІВ НА ДЕЯКІ ВЛАСТИВОСТІ РОЗЧИНІВ ТА ПЛІВОК СУКЦИНІМІДУ ХІТОЗАНУ}

Анотація. Запропоновано спосіб створення матеріалів медичного призначення з регульованими сорбиійними, фізикохімічними та деформаційно-міцнісними властивостями на основі водорозчинної похідної амінополісахарід хітозану сукиінаміда хітозану. Спосіб полягає в регулюванні прочесів агрегації макромолекул в початкових розчинах внаслідок введення органічних ко-розчинників - ацетону та етанолу.
Встановлено, що в змішаному розчиннику молекули сукиінаміда хітозану знаходяться не у вигляді ізольованих макромолекулярних клубків, а є системою взаємодіючих (агрегованих) макромолекул. Доведено, щзо за присутності ко-розчинника в системі доступність ланок макромолекул полімерів для взаємодї з ферментним препаратом зменшується, а фізикомеханічні характеристики плівкових матеріалів покрашуються.

Ключові слова: натрієва соль сукииніміду хітозану, корозчинник, відносна в язкість, ферментативна деструкція, ступінь агрегаиії, крива сорбиії. 